\title{
Herbicide Contamination of Freshwater Ecosystems: Impact on Microbial Communities
}

\author{
Villeneuve A. ${ }^{1}$, Larroudé S.2,3 and Humbert J.F. ${ }^{2}$ \\ ${ }^{1}$ Institut Pasteur, Collection des cyanobactéries, Paris \\ INRA, UMR Bioemco, Site de l'ENS \\ ${ }^{3}$ ASCONIT Consultants, Lyon \\ France
}

\section{Introduction}

Human society relies on surface freshwater ecosystems for many goods and services (drinking water, recreational facilities...), which places these systems at the center of a web of ecological, economic and political interests (Wilson \& Carpenter, 1999). They are also being subjected to increasing pressure resulting from anthropogenic activities, including contamination by a variety of mineral and organic pollutants. Most of the organic pollutants are herbicides (e.g. Kreuger, 1998; Dorigo et al., 2007), which are used not only in agriculture but also for many other purposes (ranging from domestic use in gardens to maintaining railway tracks weedfree, for example). These herbicides can enter aquatic ecosystems as a result of terrestrial runoff, and to a lesser extent, of direct application and aerial spraying (e.g. Carter, 2000). Microbial communities in freshwater ecosystems are not directly targeted, but these communities are exposed to herbicides and can be directly or indirectly affected by these compounds. For instance, many commercial herbicides act by binding to Photosystem II (PSII), which is a pigment-protein membrane complex (see e.g. Schuler \& Rand, 2008). PSII inhibitors have a direct impact on photosynthetic aquatic microorganisms that contain the same PSII apparatus as the terrestrial weeds targeted by these herbicides. In addition to this direct impact on photosynthetic microorganisms, as a result of the strong interactions that occur between all these aquatic microorganisms, herbicides can also have an indirect impact on non-photosynthetic species that are not susceptible to PSII inhibitors.

These effects on microbial communities can have a critical impact on the overall functioning of freshwater ecosystems, because prokaryotic and eukaryotic microorganisms are major players in these systems. Indeed, microorganisms contribute to most of the primary production in these systems, which is closely related to the total productivity (Aoki, 2003). They are also involved in nutrient cycling and decomposition, via the microbial loop (see, for example, the review of Fenchel, 2008). In lentic ecosystems (lakes, reservoirs, ponds...), most of these processes (primary production and nutrient cycling/decomposition) occur in the water column, and involve planktonic communities. On the other hand, in lotic ecosystems (rivers, streams...), these processes occur mainly in the biofilms located on the surface of sediments and plants, which involve benthic microbial communities. Depending on the kind of freshwater ecosystem concerned, both these communities must be considered when attempting to evaluate the impact of herbicides on microbial communities. 
In this paper, we will start by brief overview of herbicide contamination of freshwater ecosystems, focusing particularly on a few specific countries in different geographical zones. We will then go on to present the main methods used to assess the impact of herbicides on microbial communities, ranging from single species tests to field studies. The third part of this review will focus on molecular methods that have been used in the last few years to evaluate the impact of herbicides on freshwater microbial communities. The fourth section will provide a brief summary of what is known about the impact of herbicides on freshwater microbial communities, and also on how these communities respond to this selective pressure. We will then look at the data available on glyphosate, which is one of the herbicides most often found in freshwater ecosystems. Finally, we will try to relate herbicide contamination and its impact on freshwater microbial communities to global changes, which are also impacting on these communities.

\section{A rapid review of the contamination of aquatic ecosystems}

\subsection{General aspects}

The information available about herbicide contamination of surface freshwater ecosystems varies considerably from country to country. A lot of information is available for countries in Europe and North America, but the situation is more patchy for Asia and South America, and there is almost no general or local data for Africa. This can be explained by the fact that so far the heavy use of herbicides has largely been confined to North and Latin America, Europe, Japan, and Australia, although their use is rapidly increasing in many developing countries (Ware \& Whitacre, 2004). From all these data, it can be seen that even though the amount of herbicides entering the surface water varies considerably between regions, all surface freshwater ecosystems are now contaminated by herbicides. However, the concentrations of these herbicides in water vary considerably depending on the size and land use of the watersheds (e.g. Neumann et al., 2003), and also on season and climatic events. For example, peak contamination of rivers occurs just after discharge events, with relatively low levels between these events (e.g. Spalding \& Snow, 1989; Botta et al., 2009). In agricultural landscapes, the amount of pesticides contaminating surface water also depends on the methods and levels of application, and more generally on agricultural practice (Huber et al., 2000). Finally, in a recent paper of Wittmer et al. (2010), it has been shown that five types of pesticide concentration patterns in surface water samples can be distinguished, and that these patterns reveal the relative contributions made by urban and agricultural land to the contamination of water by herbicides. This paper also showed that in mixed land use catchment areas, the contamination of surface water by biocides from urban areas was at least as great as that from agricultural areas. Thus, both urban and agricultural contaminations contribute to the contamination of surface water, although the most dramatic levels occur in areas characterized by intensive agriculture (see below).

\subsection{Water contamination in some specific countries}

In France, the "Institut Français de l'Environnement" (French Institute for Environment; now known as the Service de l'Observation et des Statistiques, SOeS) has published data on the contamination of water by pesticides for every year since 1998. Their annual report is based on monitoring 453 pesticides at 2023 sampling points (groundwater and rivers). In 2007, pesticides were detected at almost $91 \%$ of the sampling points, but usually at mean 
annual concentrations of $<0.5 \mu \mathrm{g} / \mathrm{L}$. The highest concentrations were found in regions with intensive agriculture (South-West, Center-North and North of France) and the lowest in regions (South-East and South of Massif Central) characterized by less intensive agriculture or by the presence of large areas of natural environments. The pesticide most often detected in French streams was AMPA (aminomethyl phosphonic acid), which is the primary degradation product of glyphosate. The second and the third most frequently identified pesticides in streams were diuron and glyphosate, which are both herbicides. More generally, the 15 most frequently occurring pesticides were all herbicides or degradation products of herbicides. Finally, changes in herbicide concentrations in French streams from 1997 to 2007, indicate that there has been no significant decrease in the herbicide pollution of streams, but that there have been changes in the dominant compounds found in these ecosystems. For example, atrazine, which was the most frequently-found herbicide in 1997, have been less often detected since it has been banned and replaced by glyphosate (Dubois et al., 2010). Data of this type is not available for lentic ecosystems, for which only occasional analyses have been performed. To compare the situation in France with that in another European country, a recent review of Greek freshwater ecosystems has shown that atrazine, simazine, metolachlor and alachlor were the most frequently detected herbicides (Konstantinou et al., 2006). Glyphosate was not mentioned in this review, but we do not know if this was because most of the data were obtained before massive use of this herbicide began, or because Greece does not have large areas of corn production. However these studies have shown that the levels of contamination of major European rivers by herbicides such as atrazine or simazine, are similar in all countries.

We do yet have overall data for the level of contamination of surface freshwater ecosystems by herbicides in China, but three papers have provided some indications of the level of herbicide contamination in Chinese surface freshwater. Gfrerer et al. $(2002 a, b)$ have shown that triazines were detected throughout the year in three rivers from China, with a concentration peak in June due to their use in agriculture. But, apart from the June values, the concentrations of triazine were quite low compared to those in European rivers. On the other hand, in an analysis of 14 different organic pesticides and their metabolites in Lake Taihu, Na et al. (2006) reported very high concentrations of atrazine. This herbicide has been widely used in China since the 1980s, with an annual increase of $20 \%$ (in Na et al., 2006). More data are available for another Asian country, Japan. For example, in a study on the contamination of the lake Biwa, Sudo et al. (2002 \& 2004) have shown that three of the pesticides most frequently found in this lake and in the rivers flowing into it were herbicides (simetryn, molinate and bromobutide), which are all used in paddy fields, and so found in numerous rice producing areas.

It appears that triazines and in particular atrazine and simazine, are very frequently found in surface freshwater ecosystems worldwide, as are glyphosate and its degradation product, AMPA. But, local differences do occur, and are related to the kind of agriculture or to the banning of specific compounds.

\section{The main methods used to estimate the impact of herbicides on microbial communities}

Ecotoxicology deals with the evaluation of the processes and mechanisms by which toxicants are dispersed, and with their effects on populations, communities and ecosystems. This implies the need for studies at different geographical and time scales, which has resulted in the development of a wide variety of methods (Fig. 1) 


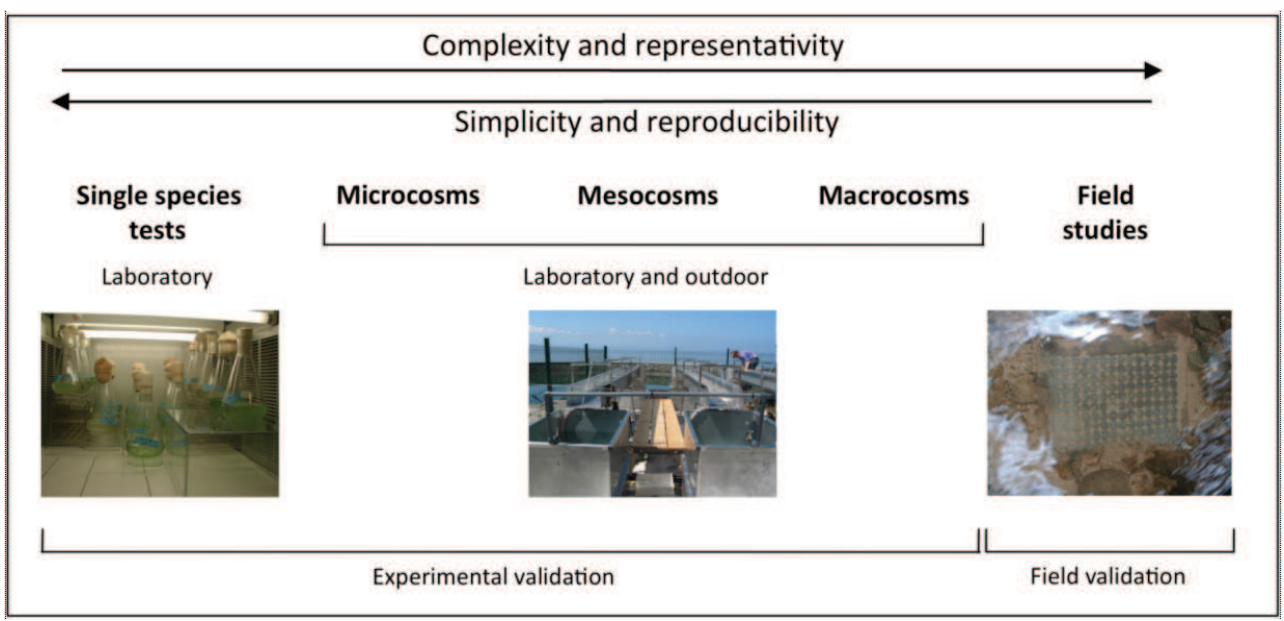

Fig. 1. Various levels of biological complexity in the experimental methods used in ecotoxicology (from Caquet et al., 1996)

Many studies are based on single-species tests, and these are usually considered to concern environmental toxicology rather than ecotoxicology (Ramade, 2007). These studies are fundamentally reductionist, and they give priority to the reproducibility of the data acquired (single-species tests and microcosm experiments). In such studies, the number of experimental parameters is limited, which makes them easier to control. In contrast, studies conducted in mesocosms or in macrocosms are closer to those performed in ecosystems, which makes them more realistic. They are designed to provide an appropriate way to assess the real impact of a pollutant in a natural ecosystem. However, these studies are more difficult to conduct, and often less reproducible, because of the large number of factors and processes involved, many of which are not easy to control.

\subsection{Single species tests}

Ecotoxicity tests are a useful way of determining the effect of one or more products on selected organisms, under defined conditions (Keddy et al., 1994). These tests can be classified according to their duration, compared to the life cycle of the organism, and to the complexity of the biological community studied. Acute toxicity tests cover a relatively short part of the life cycle of the organism. Bacteria, protists and algae have life cycles lasting 2448 hours. In contrast, chronic toxicity tests involve the repeated exposure of organisms to low doses of a contaminant over a long period.

In order to characterize the toxicity of a substance in a regulatory context, it is necessary to evaluate both its acute and chronic toxicity at several trophic levels. Various estimators have been defined in order to do this:

- $\quad \mathrm{EC}_{50}$ : The "half maximal effective concentration" is the concentration of a toxicant that induces a response halfway between the baseline and maximum response after some specified exposure time.

- LC $_{50}$ : The Lethal Concentration 50 is the concentration of a toxicant that causes $50 \%$ mortality 
- NOEC: No Observed Effect Concentration.

- LOEC: Lowest Observed Effect Concentration.

In addition to these indicators, water resource managers also use the concepts of:

- PNEC: Predicted No Effect Concentration

- PEC: Predicted Effect concentration

The $\mathrm{EC}_{50}$ value is estimated using dose-response relationships. Generally, increasing the dose of a toxicant causes a proportional increase in its toxic effect on the biological parameters investigated. The dose-response curve is based on the following assumptions:

- The response increases with dose,

- There is a threshold dose below which there is no measurable effect.

In aquatic ecosystems, algae are known to be sensitive to many chemicals, and using these organisms in test batteries has been shown to improve the capacity to predict the most sensitive ecosystem responses. The importance of these organisms in the primary production of most aquatic ecosystems justifies their choice for risk assessment. The usefulness of single or multi-species tests to characterize the ecotoxicological properties (EC50, NOEC, LOEC...) of potentially polluting molecules has been proven. Performed in the laboratory under controlled conditions, they meet repeatability, reproducibility, reliability and robustness criteria. However, their use for assessing and predicting effects on natural ecosystems is limited because of their lack of ecological realism. To address this aspect, it is necessary to work at a higher level of biological organization, i.e. with more complex experimental systems.

\subsection{Microcosms, mesocosms and macrocosms}

All these experimental systems, which differ by their volume (ranging from several $\mathrm{mL}$ to several $\mathrm{m}^{3}$ ) and their biological complexity (from a few strains to complete trophic networks), are used to study the impact of a toxicant on communities. These systems take into account both positive and negative interactions between organisms and also those with various abiotic factors. They can be used to establish an "exposure-response" relationship, rather than just a "concentration-effect". Because of the relatively large size of these systems, the tests can be conducted with long exposure times, which makes them more suitable for studying the effects of contaminants on the dynamics of species succession, and on ecological processes, such as the cycling of matter and energy flows (Guckert, 1993). These systems can also be used to evaluate the impact on diversity and functioning of the intensity of the contamination (concentration and form of contaminants) and the exposure dynamics (duration, frequency), whilst simultaneously investigating the fate and the effects of pollutants (Belanger et al., 2000). These methods can also be used to identify the temporary, progressive or persistent effects of contaminants on communities (Rand et al., 2000; Belanger et al., 2002), by measuring their resilience, and also to distinguish between the direct and indirect ecological effects of disturbances caused by contaminants (Belanger et al., 2000; Culp et al., 2000; Hense et al., 2003).

Just to provide recent examples of the variety of systems used, 3L liter Pyrex Erlenmeyer flasks have been used to study the response of microbial communities following exposure to glyphosate (Pesce et al., 2009a), indoor experimental channels have been used to study the combined effect of physical factors and exposure to diuron on benthic microbial communities (Villeneuve, 2008), and artificial outdoor mesocosms (surface area $25 \mathrm{~m}^{2}$ ) have been used by Vera et al. (2010) to evaluate the impact of Roundup on periphyton communities. 
To conclude, all these systems can be defined as essential intermediates between singlespecies tests and in situ studies (Caquet et al., 2000) in exploring the effects of toxicants and their potential interaction with environmental factors.

\subsection{Field studies to evaluate the impact of contaminants on microbial communities}

Numerous studies have attempted to evaluate the impact of herbicide contamination on microbial communities in freshwater ecosystems (see, for example, the reviews of DeLorenzo et al., 2001; Ricciardi et al., 2009). From these studies, it appears that one of the difficulties that arises is that microbial communities are subjected simultaneously to herbicides and to many other environmental factors and processes (see \$5.3). In order to evaluate the direct impact of herbicides on microbial communities, Blank et al. (1988) have developed a very interesting concept, known as PICT (Pollution Induced Community Tolerance). This concept is based on the fact that communities contain species with differing sensitivities to various chemicals (see for example for diatoms, Debenest et al., 2009). After exposure to these pollutants for long enough, sensitive species or strains will be eliminated and tolerant ones will be selected, and the resulting restructured community will become more tolerant. Increased tolerance in a community can therefore be regarded as indicative of a direct impact of a pollutant on this community (for example for microalgal communities, see Bérard et al., 2003; Schmitt-Jansen \& Altenburger, 2005). This pollution-induced community tolerance can be estimated by means of various different metabolic tests.

\section{Molecular methods used to evaluate the impact of herbicides on microbial communities}

Over the past 15 years, molecular tools have been increasingly used in ecotoxicological studies, mainly to assess the impact of pesticides on the structure and composition of microbial communities. Two approaches can be distinguished (Dorigo et al., 2005). The first group of tools uses an initial PCR to target one or several specific genes in the microbial communities, whereas the second group consists of non-PCR-approaches.

\subsection{Methods based on an initial PCR amplification}

The Polymerase Chain Reaction (PCR) is used to amplify target sequences in microbial communities. Depending on the choice of the primers, these sequences may be more or less specific, i.e. they target different taxonomic levels, ranging from a single species to the entire prokaryotic community. In most cases, rRNA genes, in particular 16S (prokaryotes) and 18S (eukaryotes) rRNA, are targeted, because they contain highly-conserved domains interspersed with more variable regions (Gutell et al., 1994). However other genes can also be used, for example those linked to a particular function, such as a herbicide degradation gene (Lee et al., 2005; de Lipthay et al., 2002).

After an initial PCR amplification, two main kinds of method are used to characterize the amplified sequences. The first is based on sequencing these amplicons and identifying the sequences obtained, for example by comparison with sequences available in databases (GenBank ${ }^{\mathrm{TM}}$ ). New sequencing technologies (454 sequencing) now make direct sequencing of the amplicons after PCR possible, but so far, sequencing is always preceded by a cloning step. Amplicon sequencing is used to compare the composition of different communities, for example with more or less exposure to a herbicide, and it provides a species identification 
when rRNA genes are used, as has been successfully done in several ecotoxicological studies of herbicides (e.g. Dorigo et al., 2002).

The second kind of methods used after PCR amplification are known as fingerprinting methods, because they provide an overview of a microbial community (like a bar code), making it easy to compare several communities. These methods include SSCP (Single Strand Conformation Polymorphism), ARISA (Automated Ribosomal Intergenic Spacer Analysis), RAPD (Random Amplified Polymorphic DNA), T-RFLP (Terminal Fragment Length Polymorphism), and AFLP (Amplified fragment-Length Polymorphism), but DGGE (Denaturing Gradient Gel Electrophoresis) and TGGE (Temperature Gradient Gel Electrophoresis) are the ones that have been most frequently used in ecotoxicological studies involving microbial communities. These two methods were first introduced 15 years ago (Muyzer, 1999). They are based on the separation of the amplified fragments of DNA on a linear gradient of increasing chemical denaturants of urea and formamide (DGGE), or on a linear temperature gradient (TGGE). After the migration, a band pattern will characterize each amplified sample, and is used to compare them. Moreover, individual bands can be excised, reamplified and sequenced, and thus identified (Riemann and Winding, 2001). DGGE/TGGE approaches have been used in a huge number of studies to characterize the impact of herbicides on microbial communities (e.g. Lyautey et al., 2003; Schauer et al., 2003; Pesce et al., 2009a; Tadonléké et al., 2009). These methods provide a quick way of comparing several samples, but they have their limitations. In particular, it is very difficult to compare large numbers of complex band patterns across several migration gels (Dorigo et al. 2005). Other limitations are due to the fact that different DNA fragments often co-migrate, which limits the sensitivity of these methods. Finally, only dominant species are detected well, which makes it difficult to highlight changes in the presence/absence of rare species.

\subsection{Non-PCR based molecular methods}

These methods have so far been used less often than those based on the PCR, but the rapid development of "omic" approaches in microbial ecology suggests that they will probably soon be used in ecotoxicology.

In recent years, a few papers have been published reporting the use of the FISH (Fluorescence in situ hybridization) technique, which is based on the use of fluorescent probes to quantify different phylogenetic groups by fluorescence microscopy. This method was used, for example, by Pesce et al. (2006), in a study of the effect of the phenylurea herbicide diuron on river microbial communities. However, this method can also be used for the in-situ detection of bacterial strains that are able to degrade herbicides, as for example by Grenni et al. (2009).

The DNA reassociation kinetics method has been also used to compare the genetic diversity of bacterial communities in more or less polluted soils (Gans et al., 2005), but not so far applied to freshwater ecosystems. This method is unlikely to be used in the near future in ecotoxicological studies in natural environments, due to the technical difficulties of applying this method in this context, and also due to the difficulty of analyzing the results.

The use of microarrays is also a very promising method developed in the past. This method is based on the use of slides (microarrays) containing a very large number of microscopic spots of DNA oligonucleotides probes (from several hundred to several thousand). These microarrays can be used to detect and quantify the species in a community after extracting 
the DNA and hybridizing it on the microarray. However, they are usually used to study the gene expression of a strain under various stressful conditions and in mixed microbial communities (Dennis et al., 2003). This method has also been used by Oldenburg et al. (2003) to monitor the diversity of the genes involved in the nitrogen cycle. However, the development of high throughput sequencing methods and the concomitant decrease in their cost will make probably the use of microarrays obsolete within a few years

\subsection{Promising new molecular tools for ecotoxicological studies}

All the methods described above have been in use for more than a decade, but there are many more recently developed methods, which look very promising for studying the impact of herbicides on freshwater microbial communities, and the responses of these communities.

Real Time PCR (RT PCR or qPCR) is not really a recent method, but its routine use in the laboratory has dramatically increased in the last year. This method can be used to determine the number of copies of target genes or the expression of target genes in a sample. For example, qPCR has been recently used by Bopp \& Lettieri (2007) to study gene regulation in a marine diatom exposed to polycyclic aromatic hydrocarbons. Another example is the work of Gonod et al. (2006), who used qPCR to study the ability of bacterial communities in soil to degrade the 2,4-D (2,4-dichlorophenoxyacetic acid) herbicide. Although so far there have been no publications involving the use of this method in freshwater environments, it will probably soon be widely used in ecotoxicological studies of microbial communities.

So far, there has also been no paper reporting the use of isotope-labeling experiments (DNASIP, RNA-SIP...) to study, for example, the bacterial degradation of herbicides in aquatic environments. However in recent review, Neufeld et al. (2007) disclaimed that isotopelabeling experiments (DNA-SIP, RNA-SIP...) are coming of age, and are likely to be very useful for studying the degradation of pollutants by microbial communities. A paper by Park et al. (2006) also highlighted the potential of Stable Isotope Probing for enhancing the resolution of ecotoxicological assessment.

Finally, the introduction of "omic" methods opens a new area in the assessment of the impact of pesticides on microbial communities. The use of metagenomic, metatranscriptomic and metaproteomic methods in recent years has shown that environmental microbial ecology is already entering the "Omics" era (see for example Nelson et al., 2006; Vandenkoornhuyse et al., 2010). Despite some restrictions, there is no doubt that all these methods will soon be major tools for ecotoxicological studies.

\section{Impact of herbicides on freshwater microbial communities}

The impact of herbicide on freshwater microbial communities depends on a large variety of factors linked to the pollutant chemical, its mechanism of action, and the time and the level of exposure... However, the impact is also modulated by interactions with physical (flow, temperature...), chemical (nutrients, organic matter, salinity...), and biological factors and processes (the presence of grazers...).

The impact of herbicides on microbial communities can be estimated using structural and functional descriptors, which provide information about the short- and long-term effects of these compounds (Fig. 2). 


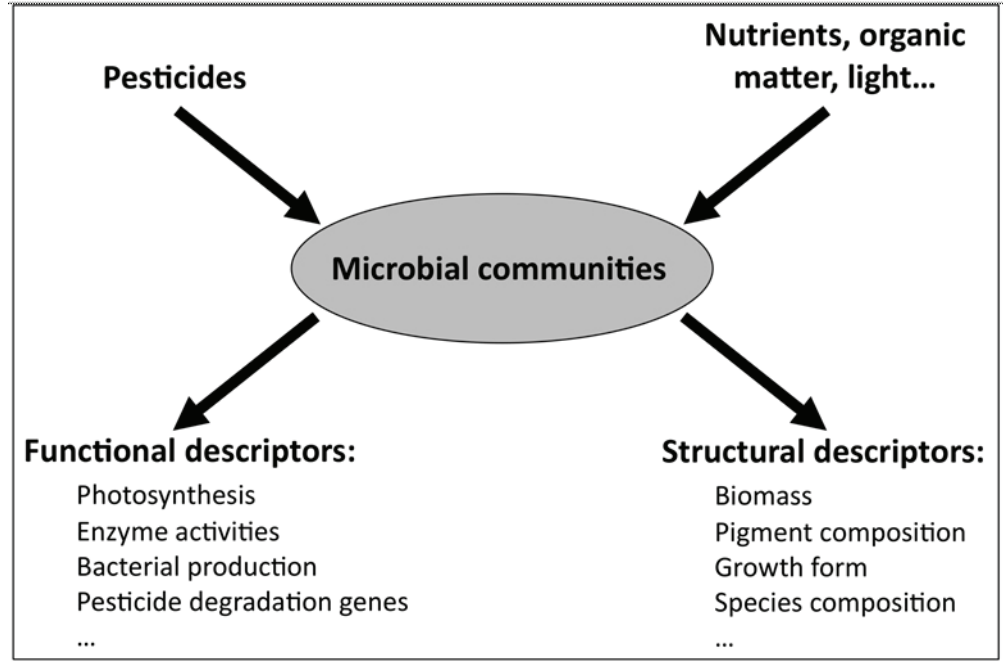

Fig. 2. Flow chart of the causes and effects of chemical and physical disturbances on microbial communities (adapted from Sabater et al., 2007)

\subsection{Impact of herbicides on the composition and structure of freshwater microbial communities}

Many authors have highlighted the fact that herbicides have significant effects on the composition and structure of freshwater microbial communities, by estimating the species richness and the diversity of autotrophic and heterotrophic microorganisms, and also by estimating their biomass and abundance.

Herbicides can have a direct impact on the composition of freshwater microbial communities by selecting those with greater herbicide resistance (Dahl \& Blanck, 1996; Pérès et al., 1996; DeLorenzo et al., 1999). For example, Dorigo et al. (2007) found that there were changes in the composition of microbial communities in a small river displaying an upstream-downstream pollution gradient, and that species located in the polluted downstream area were more tolerant towards herbicides than those located in the upstreamunpolluted area. Recently, Vera et al. (2010) have shown that diatoms were more susceptible than cyanobacteria to glyphosate in periphyton communities, and consequently that over the long term a shift occurred in the composition of these communities. In the same way, Lürling \& Roessink (2006) showed, by an experimental approach, that Scenedesmus (green algae) out competed Microcystis (Cyanobacteria) in the absence of metribuzin, a photosynthesis-inhibiting herbicide, whereas the reverse was true in the presence of this herbicide. However, herbicides can also have an indirect impact on the species composition of these communities by modifying the equilibria between species and also the interactions between them (as a result of effects on potential competitors or predators).

In addition to photosynthetic microorganisms, which are directly impacted by herbicides because they share some physiological metabolisms with terrestrial plants, these compounds can also have direct impacts on bacteria. For example, in a study of Foley et al. (2008), DGGE fingerprinting showed that freshwater bacterial communities exposed to acetochlor, an inhibitor of cell growth and division, displayed reduced diversity. However, 
contradictory results have been obtained, and, for example Tadonleke et al. (2009) did not find any significant impact of diuron, a phenylurea herbicide, on bacteria, whereas previous studies had seemed to do so.

In addition to their effects on the composition of microbial communities, herbicides can also affect the viability and abundance of microorganisms and some other cellular parameters. For example, Ricart et al. (2009) found that there was a reduction of the biovolume of diatoms at low concentrations of diuron.

Herbicide exposure usually has a harmful effect, but some microalgae bioassays of various compounds have also revealed beneficial effects (Haglund, 1997; Franqueira et al., 1999; Wong, 2000; Rioboo et al., 2002; Yoshida et al., 2003). Stimulation of microalgal growth was, for example, found at the lowest paraquat concentrations tested in the study of Prado et al. (2009). Some papers have suggested that the growth stimulation observed in the presence of herbicides, such as glyphosate, may result from the use of degradation products of this compounds as sources of carbon, phosphorus or nitrogen (Wong, 2000). In the same way, bacterial species that are able to degrade herbicides are also stimulated by their presence, thus enabling them to become dominant in bacterial communities (Macur et al., 2007).

\subsection{Impact of herbicides on the functional aspects of freshwater microbial communities}

In addition to changes occurring in the composition and structure of microbial communities, their metabolic activities (respiration, photosynthesis, enzyme activities) can also be modified by herbicide application. These modifications may or may not be linked to changes in the composition of the community.

Ricart et al. (2009) observed a marked decrease in the photosynthetic efficiency of biofilms after a long-term exposure to low concentrations of diuron. There was also an increase in the proportion of dead bacteria and in the leucine-aminopeptidase bacterial activity with increasing concentrations of diuron. This increase in peptidase activity may be explained by the release of algal material as a result of cell lysis, which might provide bacteria with organic proteinaceous compounds. Similar results have been observed for other photosystem II inhibitor herbicides in freshwater microbial communities (Guash et al., 1997, Pesce et al., 2009; Villeneuve, 2008).

The microbial community could also acclimate to the new conditions by the induction of enzyme activity, i.e. gene expression. For example by Lipthay et al. (2002) observed the induction of $t f d A$ transcription in aquatic microbial communities during acclimation to 2,4-D herbicide acid (a phenoxy herbicide, which affects protein synthesis and cell division). The $t f d A$ gene is known to encode a 2,4-D/2-oxoglutarate dioxygenase involved in the degradation of 2,4-D to dichlorophenol.

Method dealing with changes in the composition and structure of microbial communities, and in some of their physiological capacities when they are exposed to herbicide pollution, provide complementary information. Indeed, an impact on some specific functions may not necessarily affect the structure of the community and vice versa. For example, Widenfalk et al. (2008) showed that no effect of glyphosate could be detected in microbial communities from sediments exposed to this herbicide using descriptors such as bacterial production or microbial biomass, but that changes in the composition of the bacterial community could be detected using T-RFLP. 


\subsection{Interactions between environmental selective pressures and herbicide contamination}

Many studies have reported the effects of contaminants on natural freshwater microbial communities, but in all these studies, the main difficulty was distinguishing between the impact of contaminants and that of other environmental factors and processes. It is well known, for example, that the response of microbial communities to herbicides depends on the composition of the microbial community, which is itself influenced by (i) physicochemical and other factors such as nutrient resource availability (DeLorenzo et al., 2001; Shabana et al., 2001), temperature (Bérard et al., 1998), light history (Guasch \& Sabater, 1998), current velocities for periphyton communities (Villeneuve, 2008) and previous pollutant exposures (Dorigo et al., 2004), and (ii) biological interactions between microorganisms and biotic factors, such as predation by grazers (Muñoz et al., 2001). All these factors introduce seasonal variations in the structure and composition of the microbial communities of freshwater ecosystems, which influence their response to exposure to a contaminant. For example, Guash and Sabater (1998) showed that the differences in algal diversity linked to the light history of a biofilm can lead to differing responses to the presence of herbicides. Seasonal factors or spatial variability can also result in communities displaying differing diversity and differing susceptibilities to contaminants (Dorigo et al., 2009), including their ability to degrade pesticides (Pesce et al., 2009b). In a long-term laboratory experiment to test the effect of atrazine after grazing Muñoz et al. (2001) demonstrated that grazers increased the toxic effect of atrazine on river biofilms. In fact, in a context of heavy grazing, atrazine at $14 \mu \mathrm{g} / \mathrm{L}$ caused a greater decrease in periphyton carbon incorporation than either of these two factors individually. They also showed that grazing hindered adaptation to atrazine exposure. On the other hand, no significant interactions were found between diuron and grazers in a river biofilm community (LópezDoval et al., 2010).

\section{Special focus on the impact of glyphosate on freshwater microbial communities}

Glyphosate (N-(phosphomethyl)glycine), the active ingredient in the commercial product Roundup, is a broad spectrum, non-selective and post-emergent herbicide, developed in 1971 by Monsanto (Franz et al., 1997). Since 1997, its agricultural use has increased considerably as a result of the introduction of genetically-engineered "Roundup Ready" glyphosate tolerant varieties of soybean, cotton and maize (Giesy et al., 2000; Woodburn, 2000). It has become one of the most commonly-used herbicides for agricultural weed control worldwide (Giesy et al., 2000; Kolpin et al., 2006), and also for domestic and industrial weed control in gardens or along rail tracks (Woodburn, 2000; Kolpin et al., 2006; Ghanem et al., 2007; Botta et al., 2009).

\subsection{The mechanism of action and different formulations of glyphosate}

Glyphosate acts by inhibiting 5-enolpyruvyl-shikimate-3-phosphate synthase (EPSPS), which is involved in a pathway common to all higher plants as well as to some microorganisms, the shikimate pathway (Amrhein et al., 1980; Carlisle \& Trevors, 1988). As a result, it disrupts the biosynthesis of aromatic amino acids required by those organisms, for instance, to synthesize peptides, secondary metabolites or vitamins. 
The initial glyphosate molecule is a free acid, and it is converted into a salt form, such as isopropylamine (IPA), monoammonium, diammonium, or potassium salts (in newer formulations), to make it water soluble and thus to able to move into the plant (Duke, 1988; WHO, 1994). There are numerous commercial formulations, most of which are based on the IPA salt (Table 1).

\begin{tabular}{llcc}
\hline \multirow{2}{*}{ Product } & Company & \multicolumn{2}{c}{ Formulation } \\
\cline { 3 - 4 } & & g AE/L & Salt \\
\hline Touchdown HiTech & Syngenta & 500 & Potassium \\
Roundup WeatherMax & Monsanto & 540 & Potassium \\
Roundup PowerMax & Monsanto & 540 & Potassium \\
Durango DMA/Duramax & Dow AgroSciences & $/$ & Dimethylamine \\
Touchdown Total & Syngenta & 500 & Potassium \\
Roundup Ultra Max & Monsanto & 450 & IPA \\
Cornerstone & Agriliance & 356 & IPA \\
Credit & Nufarm & 356 & IPA \\
Credit Extra & Nufarm & 360 & IPA \\
Glyfos & Cheminova & 360 & IPA \\
Glyfos X-tra & Cheminova & 356 & IPA \\
Gly Star Original & Albaugh / AgriStar & 356 & IPA \\
Glyphomax & Dow AgroSciences & 356 & IPA \\
Glyphomax Plus & Dow AgroSciences & 360 & IPA \\
Honcho & Monsanto & 360 & IPA \\
Makaze & UAP & 360 & IPA \\
Roundup Original & Monsanto & 356 & IPA \\
Touchdown IQ & Syngenta & 360 & Diammonium \\
\hline
\end{tabular}

Table 1. Some of the commercial formulations of glyphosate. The acid equivalent (AE) is the corresponding weight of glyphosate acid, which is the active ingredient.

Those commercial formulations generally include a surfactant, which enhances the ability of glyphosate to penetrate through the cuticular waxes on target plants. With the exception of Roundup, in which the surfactant is known to be polyethyloxylated tallowamine (POEA), information about the surfactants involved are generally not clearly stated by the manufacturers. Furthermore, several studies have shown that the surfactant molecules also make the commercial product (in particular, Roundup) more toxic than the technical grade compound (salt or free acid forms) (Powell et al., 1991; Diamond \& Durkin, 1997; Giesy et al., 2000; Tsui \& Chu, 2003).

\subsection{Glyphosate in the environment: degradation and occurrence in freshwaters}

Glyphosate has long been assumed to be safe for the environment due to its supposed rapid biodegradation by soil microorganisms and/or the fact that it is tightly adsorbed by soil particles (Sprankle et al., 1975; Rueppel et al., 1977; Carlisle \& Trevors, 1988; Pipke \& 
Amrhein, 1988; Kolpin et al., 2006). The main degradation pathway appears to involve splitting the C-N bond to produce aminomethyl phosphonic acid (AMPA) (Rueppel et al., 1977). However, despite being biodegraded in the soil, glyphosate is frequently found in freshwater ecosystems. In these ecosystems, the herbicide is dissipated by the same microbial biodegradation as in the soil, and additionally, through its adsorption onto sediments with the subsequent microbial breakdown of bound residues under anaerobic conditions (Tooby, 1985; Mallat \& Barceló, 1998). This degradation generally occurs more slowly in water, because it contains fewer microorganisms than soil (Ghassemi et al., 1981). Glyphosate and its main degradation product AMPA are among the most common pesticides detected in water-pollution monitoring (Scribner et al., 2007). However, although glyphosate is the main source of AMPA, it is not its only source (Trass \& Smit, 2003), since phosphonate compounds can also be degraded to form AMPA (Novack, 1997; Skark et al., 1998; Kolpin et al., 2006; Botta et al., 2009).

Most studies report fairly low concentrations in surface freshwater ecosystems in regions where glyphosate use is very high (Table 2). However, a few studies have reported very high glyphosate concentrations, such as 700 or $1700 \mu \mathrm{g} / \mathrm{L}$ in some ecosystems (Table 2). These very large differences in concentrations may arise from differences in (i) the proximity of the site of application to water-bodies, (ii) terrain and soil types and also (iii) the contribution of overspray (WHO, 1994). In general, these differences suggest the possibility of short-term pulse phenomena, which are likely to occur in water contamination as previously found for other herbicides (e.g. Wauchope, 1978; Shipitalo \& Owens, 2006; Gilliom, 2007).

\subsection{Impact of glyphosate on aquatic microorganisms}

There have been numerous studies of the toxicity of glyphosate on freshwater prokaryotic and eukaryotic photosynthetic microorganisms (Table 3), but most of them have been based on the use of isolated strains in laboratory experiments.

As Table 3 shows, a lot of data is available about the toxicity of glyphosate towards the Chlorophyceae and Cyanobacteria, and to a lesser extent towards diatoms. These data show that widely differing $\mathrm{EC}_{50}$ values have been found, depending on the species and formulations involved. For example, the Chlorophyceae exhibited $\mathrm{EC}_{50}$ values ranging between 2.1 and $1082 \mathrm{mg} / \mathrm{L}$ and Chlorella pyrenoidosa, $\mathrm{EC}_{50}$ values of between 3.5 and $590 \mathrm{mg} / \mathrm{L}$. These wide differences could arise as a result of differences in study design, such as the duration of the experiments, the glyphosate formulation used (e.g. Sáenz et al., 1997), which is not always clearly identified, and the $\mathrm{EC}_{50}$ measurements, which may be based on the biomass, the chlorophyll concentration, or on the carbon uptake. In the same way, the Cyanobacteria, which are photosynthetic prokaryotes, exhibited a wide range of $\mathrm{EC}_{50}$ values varying from 2 to $1183 \mathrm{mg} / \mathrm{L}$. However, despite this variability in EC 50 values, Cyanobacteria in general appear to be less sensitive to glyphosate than eukaryotic photosynthetic microorganisms (Powell et al., 1991). This tolerance of glyphosate could be explained by various mechanisms, notably the ability of Cyanobacteria to metabolize phosphonate (Forlani et al., 2008). Little data is available about the toxicity of the main degradation product AMPA. As far as we are aware, the only values reported for its $\mathrm{EC}_{50}(72 \mathrm{~h})$ are $72.9 \mathrm{mg} / \mathrm{L}$ and $79.7 \mathrm{mg} / \mathrm{L}$ for the Chlorophycea species Scenedesmus subpicatus (Trass \& Smit, 2003; AFSSA, 2006). These values are consistent with the hypothesis that the toxicity of AMPA is equal to or less than that of glyphosate (Carlisle \& Trevors, 1988; Giesy et al., (2000). 


\begin{tabular}{|c|c|c|c|c|c|c|}
\hline & \multirow{2}{*}{$\begin{array}{l}\text { Time } \\
\text { period }\end{array}$} & \multicolumn{2}{|c|}{$\begin{array}{c}\text { Glyphosate } \\
(\mu \mathrm{g} / \mathrm{L})\end{array}$} & \multicolumn{2}{|c|}{$\begin{array}{c}\text { AMPA } \\
(\mu \mathrm{g} / \mathrm{L})\end{array}$} & \multirow[t]{2}{*}{ Reference } \\
\hline & & Min & Max & Min & Max & \\
\hline \multicolumn{7}{|l|}{ Canada } \\
\hline Rivers, streams \& wetlands & 2004-05 & 1 & 41 & / & 66 & Struger et al., 2008 \\
\hline $\begin{array}{l}\text { Urban \& rural watersheds } \\
\text { USA }\end{array}$ & 2007 & 0.02 & 12 & 0.04 & 1.3 & Byer et al., 2008 \\
\hline Stream & 1987 & 35 & 1237 & $<1.0$ & 10 & Monsanto, 1990 \\
\hline Pond & 1987 & 90 & 1700 & 2 & 35 & Monsanto, 1990 \\
\hline $\begin{array}{l}\text { Streams, rivers, lakes, } \\
\text { wetlands \& vernal pools }\end{array}$ & 2001-06 & 0.02 & 427 & 0.02 & 41 & $\begin{array}{l}\text { Scribner et al., } \\
\quad 2007\end{array}$ \\
\hline Stream & 2002 & 0.1 & 8.7 & 0.4 & 3.6 & $\begin{array}{l}\text { Battaglin et al., } \\
\qquad 2005\end{array}$ \\
\hline $\begin{array}{l}\text { Streams \& } \\
\text { wastewater effluents }\end{array}$ & 2002 & $<0.1$ & 2.2 & $<0.1$ & 3.9 & Kolpin et al., 2006 \\
\hline Vernal pools & 2005-06 & $\begin{array}{c}<0.0 \\
2\end{array}$ & 328 & $\begin{array}{c}<0.0 \\
2\end{array}$ & 41 & $\begin{array}{l}\text { Battaglin et al., } \\
2009\end{array}$ \\
\hline \multicolumn{7}{|l|}{ Argentina } \\
\hline Streams & 2003-04 & 100 & 700 & / & / & $\begin{array}{l}\text { Peruzzo et al., } \\
2008\end{array}$ \\
\hline \multicolumn{7}{|l|}{ France } \\
\hline NR & 1999 & / & 6.06 & / & 5.05 & $\begin{array}{c}\text { Horth \& } \\
\text { Blackmore, } 2009\end{array}$ \\
\hline NR & 2000 & / & 35 & / & 2.99 & $\begin{array}{c}\text { Horth \& } \\
\text { Blackmore, } 2009\end{array}$ \\
\hline Streams \& rivers & 2003-04 & 2 & 165 & 2.1 & 48.1 & IFEN, 2006 \\
\hline River & 2003 & 0.23 & 0.74 & 0.17 & 3.76 & Pesce et al., 2008 \\
\hline NR & 2004 & / & 50 & / & 17 & $\begin{array}{c}\text { Horth \& } \\
\text { Blackmore, } 2009\end{array}$ \\
\hline Streams \& rivers & 2005 & 2.1 & 17 & 2.1 & 18.8 & IFEN, 2007 \\
\hline NR & 2005 & / & 9.6 & / & 30 & $\begin{array}{c}\text { Horth \& } \\
\text { Blackmore, } 2009\end{array}$ \\
\hline Streams \& rivers & 2006 & 2.0 & 34.0 & 2.2 & 27.5 & $\begin{array}{c}\text { Horth \& } \\
\text { Blackmore, 2009; } \\
\text { IFEN, } 2009\end{array}$ \\
\hline \multicolumn{7}{|l|}{ Sweden } \\
\hline NR & $2000-08$ & 0.06 & 13 & 0.07 & 4 & $\begin{array}{c}\text { Horth \& } \\
\text { Blackmore, } 2009\end{array}$ \\
\hline
\end{tabular}

$\mathrm{NR}$ = type of water not reported; / = no data.

Table 2. Data available on glyphosate and AMPA concentrations in surface water 


\begin{tabular}{|c|c|c|c|c|}
\hline & $\begin{array}{l}\text { Glyphosate } \\
\text { formulation }\end{array}$ & $\begin{array}{c}\mathrm{EC}_{50} \\
(\mathrm{mg} / \mathrm{L})\end{array}$ & $\begin{array}{c}\text { European } \\
\text { toxicity } \\
\text { classification }\end{array}$ & Reference \\
\hline \multicolumn{5}{|l|}{ Bacillariophyceae } \\
\hline Nitzschia sp. & IPA salt & $<2.8$ & $\begin{array}{l}\text { Toxic to very } \\
\text { toxic }\end{array}$ & Peterson et al., 1994 \\
\hline Cyclotella meneghiana & IPA salt & $<2.8$ & $\begin{array}{l}\text { Toxic to very } \\
\text { toxic }\end{array}$ & \\
\hline \multirow[t]{4}{*}{ Navicula pelliculosa } & $96.6 \%$ & 39.9 & Harmful & Hughes, 1987b M \\
\hline & Acid & 17 & Harmful & $\begin{array}{l}\text { Office of pesticides } \\
\text { programs, } 2000 ; \\
\text { Smyth et al., } 1996^{\mathrm{M}}\end{array}$ \\
\hline & & 42 & Harmful & Smyth et al., 1996M \\
\hline & IPA salt & 38.6 & Harmful & $\begin{array}{l}\text { Office of pesticides } \\
\text { programs, } 2000\end{array}$ \\
\hline \multicolumn{5}{|l|}{ Chlorophyceae } \\
\hline \multirow[t]{2}{*}{ Scenedesmus obliquus } & $95 \%$ & 55.9 & Harmful & Ma, 2002 \\
\hline & Knockdown & 80 & Harmful & Ermis \& Demir, 2009 \\
\hline \multirow[t]{6}{*}{ Scenedesmus quadricauda } & $95 \%$ & 70.5 & Harmful & Ma et al., 2003 \\
\hline & IPA salt & $>>2.8$ & & Peterson et al., 1994 \\
\hline & & 7.2 & Toxic & $\begin{array}{l}\text { Sáenz \& Di Marzio, } \\
2009\end{array}$ \\
\hline & & 9.02 & Toxic & Sáenz et al., 1997 \\
\hline & Rondo & 7.2 & Toxic & Sáenz et al.1997 \\
\hline & Roundup & 120 & $\mathrm{NC}$ & $\begin{array}{l}\text { Sáenz \& Di Marzio, } \\
2009\end{array}$ \\
\hline \multirow[t]{4}{*}{ Scenedesmus acutus } & $97.5 \%$ & 24.5 & Harmful & Vendrell, et al., 2009 \\
\hline & IPA salt & 10.2 & Harmful & Sáenz, et al., 1997 \\
\hline & & 10.2 & Harmful & $\begin{array}{l}\text { Sáenz \& Di Marzio, } \\
2009\end{array}$ \\
\hline & Rondo & 9.08 & Toxic & Sáenz, et al., 1997 \\
\hline \multirow[t]{2}{*}{ Scenedesmus subscapitatus } & $97.5 \%$ & 26 & Harmful & Vendrell et al., 2009 \\
\hline & IPA salt & 72.9 & Harmful & Tomlin, 1997 \\
\hline Chlorella saccharophila & $97.5 \%$ & 40.6 & Harmful & Vendrell et al., 2009 \\
\hline \multirow[t]{3}{*}{ Chlorella vulgaris } & $97.5 \%$ & 41.7 & Harmful & Vendrell et al., 2009 \\
\hline & $95 \%$ & 4.7 & Toxic & Ma et al., 2002 \\
\hline & IPA salt & 13.1 & Harmful & $\begin{array}{l}\text { Sáenz \& Di Marzio, } \\
2009\end{array}$ \\
\hline Chlorella pyrenoidosa & $96.7 \%$ & 590 & $\mathrm{NC}$ & $\begin{array}{l}\text { Maule \& Wright, } \\
1984\end{array}$ \\
\hline
\end{tabular}




\begin{tabular}{|c|c|c|c|c|}
\hline & $\begin{array}{l}\text { Glyphosate } \\
\text { formulation }\end{array}$ & $\begin{array}{l}\mathrm{EC}_{50} \\
(\mathrm{mg} / \mathrm{L})\end{array}$ & $\begin{array}{c}\text { European } \\
\text { toxicity } \\
\text { classification }\end{array}$ & Reference \\
\hline & \multirow[t]{2}{*}{$95 \%$} & 3.5 & Toxic & Ma \& Wang, 2002 \\
\hline & & 3.5 & Toxic & Ma, 2002 \\
\hline & Roundup & 189 & $\mathrm{NC}$ & Hernando et al., 1989 \\
\hline & NR & 380 & NC & Anton et al., 1993 \\
\hline & NR & 1082 & NC & Anton et al., 1993 \\
\hline Chlorella fusca & NR & 377 & NC & Faust et al., 1993 \\
\hline Chlorococcum hypnosporum & $96.7 \%$ & 68 & Harmful & $\begin{array}{l}\text { Maule \& Wright, } \\
1984\end{array}$ \\
\hline \multirow[t]{15}{*}{$\begin{array}{l}\text { Pseudokirchneriella } \\
\text { subcapitata }{ }^{1}\end{array}$} & \multirow[t]{5}{*}{$96.6 \%$} & 12.5 & Harmful & $\begin{array}{l}\text { Office of pesticide } \\
\text { programs, } 2000\end{array}$ \\
\hline & & 13.8 & Harmful & Hughes, 1987c M \\
\hline & & 460 & $\mathrm{NC}$ & Smyth et al., 1995 M \\
\hline & & 485 & NC & Smyth et al., 1995 M \\
\hline & & 270 & NC & $\begin{array}{l}\text { Cedergreen \& } \\
\text { Streibig, } \\
2005\end{array}$ \\
\hline & \multirow[t]{2}{*}{$95 \%$} & 21.8 & Harmful & $\begin{array}{l}\text { Bozeman \& } \\
\text { Koopman , } 1989\end{array}$ \\
\hline & & 129 & NC & Pereira et al., 2009 \\
\hline & \multirow[t]{2}{*}{ IPA salt } & 24.7 & Harmful & Tsui \& Chu, 2003 \\
\hline & & 41 & Harmful & Tsui \& Chu, 2003 \\
\hline & \multirow[t]{4}{*}{ Roundup } & 5.8 & Toxic & Tsui \& Chu, 2003 \\
\hline & & 2.1 & Toxic & LISEC, 1989a M \\
\hline & & 8 & Toxic & LISEC, 1989a M \\
\hline & & 64.7 & Harmful & $\begin{array}{l}\text { Cedergreen \& } \\
\text { Streibig, } 2005\end{array}$ \\
\hline & Spasor & 71 & Harmful & Pereira et al., 2009 \\
\hline & Sting & 2.5 & Toxic & LISEC, 1989b M \\
\hline \multicolumn{5}{|l|}{ Cyanobacteria } \\
\hline \multirow[t]{2}{*}{ Microcystis aeruginosa } & Acid & 110 & NC & $\begin{array}{l}\text { López-Rodas et al., } \\
2007\end{array}$ \\
\hline & NR & $169^{* *}$ & NC & Forlani, 2008 \\
\hline Anabaena sp. & NR & $338^{* *}$ & NC & Forlani, 2008 \\
\hline \multirow[t]{3}{*}{ Anabaena flos aquae } & $96.7 \%$ & 304 & NC & $\begin{array}{l}\text { Maule \& Wright, } \\
1984\end{array}$ \\
\hline & $96.6 \%$ & 11.7 & Harmful & Hughes, 1987aM \\
\hline & Acid & 15 & Harmful & Smyth et al., 1996M \\
\hline Anabaena varialis & Acid & 2 & Toxic & Hutber et al., 1979 \\
\hline
\end{tabular}




\begin{tabular}{lccll}
\hline & $\begin{array}{c}\text { Glyphosate } \\
\text { formulation }\end{array}$ & $\begin{array}{c}\mathbf{E C}_{\mathbf{5 0}} \\
\mathbf{( m g / L )}\end{array}$ & $\begin{array}{c}\text { European } \\
\text { toxicity } \\
\text { classification }\end{array}$ & Reference \\
\hline Aphanocapsa 6308 & Acid & 2 & Toxic & Hutber et al., 1979 \\
Aphanocapsa 6714 & Acid & 100 & Harmful & Hutber et al., 1979 \\
Nostoc sp. & Acid & 2 & Toxic & Hutber et al., 1979 \\
Nostoc punctiform & NR & $1183^{*}$ & NC & Forlani, 2008 \\
Aphanizomenon flos-aquae & IPA salt & $<2.85$ & $\begin{array}{l}\text { Toxic to very } \\
\text { toxic }\end{array}$ & Peterson et al., 1994 \\
\hline
\end{tabular}

1 formerly, Selenastrum capricornutum; $\mathrm{NR}=$ not reported; $>>=$ considerably more than; $\mathrm{NC}=\mathrm{no}$ classification for this range; ${ }^{*}$ estimation of $\mathrm{EC}_{50}$ value based on graph; $\mathrm{M}=$ unpublished studies performed by the Manufacturers (Monsanto, Zeneca, Malcolm Pirnie)

Table 3. Overview of aquatic microorganism toxicity of various formulations of glyphosate

All these toxicity tests are simple ways of assessing the direct impacts of glyphosate on freshwater microorganisms, but they cannot be used to assess the real impact of this compound on natural populations and communities in freshwater ecosystems. For this reason, many experimental studies have attempted to use complex communities. Two papers by Goldsborough \& Brown (1988) and Austin et al. (1991) found that glyphosate had no major impact on periphyton communities. However, Austin et al. (1991) suggested that the degradation of glyphosate could increase the concentration of soluble phosphorus, and consequently increase the biomasses of the communities. Subsequently, Vera et al. (2010) showed that the periphytic colonization of substrata was delayed in Roundup-contaminated large mesocosms, and that this phenomenon could be attributed to a direct effect of the contaminant. In addition they showed that in periphyton communities Roundup produced a long-term shift in the typology and functioning of contaminated mesocosms, which was consistent with data available from natural lakes in the Argentine Pampas. Another recent paper by Pérez et al. (2007) has also demonstrated an impact of Roundup on the structure of the phytoplankton and periphyton communities, and more particularly a decrease in the total micro- and nanophytoplankton and an increase in picocyanobacteria. Moreover, they have shown that these changes are more likely to be due to a direct toxic effect of glyphosate rather than to an indirect effect via a phosphorus enrichment of the streams linked to the degradation of this compound.

To conclude, herbicides containing glyphosate seem to have direct toxicological effects on non-target periphyton and phytoplankton communities in freshwater ecosystems, as well as indirect effects via the eutrophication potential of glyphosate degradation. These communities constitute the basis of food webs in these ecosystems, and so it would appear that glyphosate can potentially impact the overall functioning of freshwater ecosystems. This potential impact is reinforced by the fact that this compound is also known to be toxic for fish (e.g. Langiano \& Martinez, 2008; Cavalcante et al., 2008), and could be involved in a trophic cascading process (Bengtsson et al., 2004).

\section{Conclusions}

As we have seen, a lot of data is available about the contamination of freshwater ecosystems by herbicides and also on the direct or indirect impact of these compounds on microbial 
communities living in these ecosystems. These compounds appear to affect the structure and composition of these communities, and also the metabolism of the microorganisms involved. It is very difficult to evaluate the consequences of such changes on the whole functioning of freshwater ecosystems, but there can be no doubt that it is significantly affected by herbicide contamination, because microbial communities play a key role in these ecosystems. This impact is probably reinforced by the fact that freshwater ecosystems are simultaneously subjected to other selective pressures. For example, herbicide pollution is generally concomitant with pollution by mineral nutrients (phosphorus and nitrogen), which also influence the structure and the functioning of microbial communities. In the same way, even though only a small number of papers have been published on the topic, we know that climate change is already affecting aquatic microbial communities (e.g. Falkowski \& Oliver, 2007; Jöhnk et al., 2008).

The situation concerning herbicide contamination of freshwater ecosystems will change in the next few years, as a result of changes in agricultural practice. In a developed country like France, a drastic reduction of herbicide $(50 \%)$ use is planned within a short time scale $(<10$ years). The European community as a whole is also engaged in reducing the use of pesticides in agriculture. In contrast, demographic pressure and Biofuel production in some areas of the world, such as Asia and South America, are leading to increasingly intensive agricultural practices, and consequently to growing herbicide pollution of freshwater ecosystems. These divergent situations will probably result in sharply contrasting situations with regard to the herbicide pollution of aquatic ecosystems in these different regions.

\section{References}

AFSSA (2006). Database of the INRA: AGRITOX. http://www.dive.afssa.fr/agritox /index.php (accessed in July 2010).

Amrhein, N.; Schab, J. \& Steinrücken, H.C. (1980). The mode of action of the herbicide glyphosate. Naturwissenschaften, 67, 356-357.

Anton, F.A.; Ariz, M. \& Alia, M. (1993). Ecotoxic effects of four herbicides (glyphosate, alachlor, chlortoluron and isoproturon) on the algae Chlorella pyrenoidosa chick. Science of the Total Environment, Supplement, 845-851.

Aoki, I. (2003). Diversity-productivity-stability relationship in freshwater ecosystems: Whole-systemic view of all trophic levels. Ecological Research, 18, 397-404.

Austin, A.P.; Harris, G.E. \& Lucey, W.P. (1991). Impact of an organophosphate herbicide (Glyphosate $\left.{ }^{\circledR}\right)$ on periphyton communities developed in experimental streams. Bulletin of Environmental Contamination and Toxicology, 47, 29-35.

Battaglin, W.A.; Kolpin, D.W.; Scribner; E.A.; Kuivila, K.M. \& Sandstrom, M.W. (2005). Glyphosate, other herbicides and transformation products in midwestern streams, 2002. Journal Of The American Water Resources Association, 41, 323-332.

Battaglin, W.A.; Rice, K.C.; Focazio, M.J.; Salmons, S. \& Barry, R.X. (2009). The occurrence of glyphosate, atrazine, and other pesticides in vernal pools and adjacent streams in Washington , DC, Maryland, Iowa, and Wyoming, 2005-2006. Environmental Monitoring and Assessment, 155, 281-307.

Belanger, S.E.; Bowling, J.W.; Lee, D.M.; LeBlanc, E.M.; Kerr, K.M.; McAvoy, D.C.; Christman, S.C. \& Davidson, D.H. (2002). Integration of aquatic fate and ecological responses to linear alkyl benzene sulfonate (LAS) in model stream ecosystems. Ecotoxicology and Environmental Safety, 52, 150-171. 
Belanger, S.E.; Guckert, J.B.; Bowling, J.W.; Begley, W.M.; Davidson, D.H.; LeBlanc, E.M. \& Lee, D.M. (2000). Responses of aquatic communities to 25-6 alcohol ethoxylate in model stream ecosystems. Aquatic Toxicology, 48, 135-150.

Bengtsson, G.; Hansson, L.A. \& Montenegro, K. (2004). Reduced grazing rates in Daphnia pulex caused by contaminants: Implications for trophic cascades. Environmental Toxicology and Chemistry, 11, 2641-2648.

Bérard, A.; Dorigo, U.; Mercier, I.; Becker-van-Slooten, K.; Grandjean, D. \& Leboulanger, C. (2003). Comparison of the ecotoxicological impact of the triazines Irgarol 1051 and atrazine on microalgal cultures and natural microalgal communities in Lake Geneva. Chemosphere, 53, 935-944.

Bérard, A.; Pelte, T.; Menthon, E.; Druart, J.C. \& Bourrain, X. (1998). Characterisation of phytoplankton from two limnic systems contaminated by a herbicidal photosynthetic inhibitor. The PICT method (Pollution-Induced Community Tolerance): application and significance. Annales de Limnologie-International Journal of Limnology, 34, 269-282.

Blank, H.; Wängberg, S.A. \& Molander, S. (1988). Pollution-induced community tolerance-a new ecotoxicological tool. In: Functional testing of aquatic biota for estimating hazards of chemicalsJ. Cairns, Jr. and J.R. Pratt, Editors, ASTM STP 988, American Society for Testing and Materials, Philadelphia, pp. 219-230.

Bopp, S.K. \& Lettieri, T. (2007). Gene regulation in the marine diatom Thalassiosira pseudonana upon exposure to polycyclic aromatic hydrocarbons (PAHs). Gene, 396, 293-302.

Botta, F.; Lavison, G.; Couturier, G.; Alliot, F.; Moreau-Guigon, E.; Fauchon, N.; Guery, B.; Chevreuil, M. \& Blanchoud, H. (2009). Transfer of glyphosate and its degradate AMPA to surface waters through urban sewerage systems. Chemosphere, 77, 133139.

Bozeman, J.; Koopman, B. \& Bitton, G. (1989). Toxicity testing using immobilized algae. Aquatic Toxicology, 14, 345-352.

Byer, J.D.; Struger, J.; Klawunn, P.; Todd, A. \& Sverko, E. (2008). Low cost monitoring of glyphosate in surface waters using the ELISA method: An evaluation. Environmental Science and Technology, 42, 6052-6057.

Caquet, T.; Lagadic, L. \& Sheffield, S. R. (2000). Mesocosms in ecotoxicology (1): Outdoor aquatic systems. In: Reviews of Environmental Contamination and Toxicology. 165, 1-38.

Caquet, T.; Lagadic, L.; Jonot, O.; Baturo, W.; Kilanda, M.; Simon, P.; LeBras, S.; Echaubard, M. \& Ramade, F. (1996). Outdoor experimental ponds (mesocosms) designed for long-term ecotoxicological studies in aquatic environment. Ecotoxicology and Environmental Safety, 34, 125-133.

Carlisle, S.M. \& Trevors, J.T. (1988). Glyphosate in the environment. Water, Air and Soil Pollution, 39, 409-420.

Carter, A. (2000). How pesticides get into water - and proposed reduction measures. Pesticide Outlook, 2000, 149-156.

Cavalcante, D.G.S.M.; Martinez, C.B.R. \& Sofia, S.H. (2008). Genotoxic effects of Roundup ${ }^{\circledR}$ on the fish Prochilodus lineatus. Mutation Research/Genetic Toxicology and Environmental Mutagenesis, 655, 41-46. 
Cedergreen, N. \& Streibig, J.C. (2005). The toxicity of herbicides to non-target aquatic plants and algae: assessment of predictive factors and hazard. Pesticide Management Science, 61, 1152-1160.

Culp, J. M.; Podemski, C. L.; Cash, K. J. \& Lowell, R. B. (2000). A research strategy for using stream microcosms in ecotoxicology : integrating experiments at different levels of biological organization with field data. Journal of Aquatic Ecosystem Stress and Recovery, 7, 167-176.

Dahl, B. \& Blanck, H. (1996). Toxic effects of the antifouling agent Irgarol 1051 on periphyton communities in coastal water microcosms. Marine Pollution Bulletin. 32, 342-350.

de Lipthay, J.R.; Aamand, J. \& Barkay, T. (2002). Expression of $t f d A$ genes in aquatic microbial communities during acclimation to 2,4-dichlorophenoxyacetic acid. FEMS Microbiology Ecology, 40, 205-214.

Debenest, T.; Pinelli, E.; Coste, M.; Silvestre, J.; Mazzella, N.; Madigou, C. \& Delmas, F. (2009). Sensitivity of freshwater periphytic diatoms to agricultural herbicides. Aquatic Toxicology, 93, 11-17.

DeLorenzo, M.E.; Scott, G. I. \& Ross, P.E. (1999). Effects of the agricultural pesticides atrazine, deethylatrazine, endosulfan, and chlorpyrifos on an estuarine microbial food web. Environmental Toxicology and Chemistry, 18, 2824-2835.

DeLorenzo, M.E.; Scott, G.I. \& Ross P.E. (2001). Toxicity of pesticides to aquatic microorganisms: a review. Environmental Toxicology and Chemistry. 20, 84-98.

Dennis, P.; Edwards, E.A.; Liss, S.N. \& Fulthorpe R. (2003). Monitoring gene expression in mixed microbial communities by using DNA microarrays. Applied and Environmental Microbiology, 69, 769-778.

Diamond, G.L. \& Durkin, P.R. (1997). Effects of surfactants on the toxicitiy of glyphosate, with specific reference to Rodeo. Prepared under USDA FS Contract No. 53- 3187-512. Final Report.

Dorigo, U.; Bérard, A. \& Humbert, J.F. (2002). Comparaison of eukaryotic phytobenthic community composition in a polluted river by $18 \mathrm{~S}$ rRNA gene cloning and sequencing. Microbial Ecology, 44,372-380.

Dorigo, U.; Bourrain, X.; Bérard, A. \& Leboulanger, C., (2004). Seasonal changes in the sensitivity of river microalgae to atrazine and isoproturon along a contamination gradient. Science of the Total Environment. 318, 101-114.

Dorigo, U.; Leboulanger, C.; Bérard, A.; Bouchez, A.; Humbert, J.F. \& Montuelle, B. (2007). Lotic biofilm community structure and pesticide tolerance along a contamination gradient in a vineyard area. Aquatic Microbial Ecology, 50, 91-102.

Dorigo, U.; Lefranc, M.; Bouchez, A.; Montuelle, B. \& Humbert, J.F. (2009). Spatial heterogeneity of periphytic microbial communities in a small pesticide-polluted river. FEMS Microbial Ecology, 67, 491-501

Dorigo, U.; Volatier, L. \& Humbert, J.F. (2005). Molecular approaches to the assessment of biodiversity in aquatic microbial communities. Water Research, 39, 2207-2218.

Dubois, A.; Lacouture, L. \& Feuillet, C. (2010). Les pesticides dans les milieux aquatiques données 2007. Etude et documents. Commissariat Général au développement durable-Service de l'observation et des statistiques, 49 pp. (in French)

Duke, S.O. (1988). Glyphosate, In: Herbicides: chemistry, degradation and mode of action, Vol. 3, Kearney P.C. \& Kaufman D.D. (Ed), 1-70, Marcel Dekker, New York, NY. 
Ermis, U.B. \& Demir, N. (2009). Toxicity of glyphosate and ethoxysulfuron to the green microalgae (Scenedesmus obliquus). Asian Journal of Chemistry, 21, 2163-2169.

Falkowski, P.G. \& Oliver, M.J. (2007). Mix and match: how climate selects phytoplankton. Nature Reviews Microbiology, 5, 813-820.

Faust, M.; Altenburger, R.; Boedeker, W. \& Grimme, L. (1993). Additive effects of herbicide combinations on aquatic non-target organisms. The Science of the Total Environment, Supplement, 941-952.

Fenchel, T. (2008). The microbial loop - 25 years later. Journal of Experimental Marine Biology and Ecology, 366, 99-103.

Foley, M.E.; Sigler, V. \& Gruden, C.L. (2008). A multiphasic characterization of the impact of the herbicide acetochlor on freshwater bacterial communities. The ISME Journal. 2, 56-66.

Forlani, G.; Pavan, M.; Gramek, M.; Kafarski, P. \& Lipok, J. (2008). Biochemical bases for a widespread tolerance of Cyanobacteria to the phosphonate herbicide Glyphosate. Plant E Cell Physiology, 49, 443-456.

Franqueira, D.; Cid, A.; Torres, E.; Orosa, M. \& Herrero, C. (1999). A comparison of the relative sensitivity of structural and functional cellular responses in the alga Chlamydomonas eugametos exposed to the herbicide paraquat. Archive of Environmental Contamination and Toxicology, 36, 264-269.

Franz, J.E.; Mao, M.K. \& Sikorski, J.A. (1997). Glyphosate: A unique global herbicide. American Chemistry Society, ASC Monographs, 189, 1-600.

Gans, J.; Wolinsky, M. \& Dunbar, J. (2005). Computational improvements reveal great bacterial diversity and high metal toxicity in soil. Science, 309, 1387-1390

Gfrerer, M.; Martens, D.; Gawlik, B.M.; Wenzl, T.; Zhang, A.; Quan, X.; Sun, C.; Chen, J.; Platzer, B.; Lankmayr, E. \& Kettrup, A. (2002a). Triazines in the aquatic systems of the Eastern Chinese Rivers Liao-He and Yangtse. Chemosphere, 47, 455-66.

Gfrerer, M.; Wenzl, T.; Quan, X.; Platzer, B. \& Lankmayr, E. (2002b). Occurrence of triazines in surface and drinking water of Liaoning Province in Eastern China. Journal of Biochemical and Biophysical methods, 53, 217-28.

Ghanem, A.; Bados, P.; Estaun, A.R.; de Alencastro, L.F.; Taibi, S.; Einhorn, J. et al. (2007). Concentrations and specific loads of glyphosate, diuron, atrazine, nonylphenol and metabolites thereof in French urban sewage sludge. Chemosphere, 69, 1368-1373.

Ghassemi, M.; Fargo, L.; Painter, P.; Quinlivan, S.; Scofield, R.; Takata., A. et al. (1981). Environmental fates and impacts of major forest use pesticides. EPA contract No. 68-02-3174. Environmental Protection Agency, Washington, DC. Washington, DC.

Goldsborough, L.G. \& Brown D.J. (1988). Effect of Glyphosate (Roundup ${ }^{\circledR}$ formulation) on periphytic algal phosotosynthesis. Bulletin of Environmental Contamination and Toxicology, 41, 253-260.

Giesy, J.P.; Dobson, S. \& Solomon, K.R. (2000). Ecotoxicological risk assessment for Roundup herbicide. Review of Environmental Contamination and Toxicology, 167, 35-120.

Gilliom, R.J. (2007). Pesticides in US streams and groundwater. American Chemistry Society, Environmental Science and Technology, 15, 3408-3414.

Gonod, L.; Martin-Laurent, F. \& Chenu, C. (2006). 2,4D impact on bacterial communities, and the activity and genetic potential of $2,4 \mathrm{D}$ degrading communities in soil. FEMS Microbiology Ecology, 58, 529-537 
Grenni, P.; Gibello, A.; Barra Caracciolo, A.; Fajardo, C.; Nande, M.; Vargas, R.; Sacca, M.L.; Martinez-Inigo, M.J.; Ciccoli, R. \& Martin M. (2009). A new fluorescent oligonucleotide probe for in situ detection of s-triazine-degrading Rhodococcus wratislaviensis in contaminated groundwater and soil samples. Water Research, 43, 2999-3008

Guasch, H. \& Sabater, S. (1998). Light history influences the sensitivity to atrazine in periphytic algae. Journal of Phycology, 34, 233-241

Guasch, H.; Munoz, I.; Roses, N. \& Sabater, S. (1997). Changes in atrazine toxicity throughout succession of stream periphyton communities. Journal of Applied Phycology, 9, 137-146.

Guckert, J.B. (1993). Artificial streams in ecotoxicology. In: Lamberti G.A. et Steinman A.D. Research in artificial streams : applications, uses and abuses. Journal of National American Benthology Society, 12, 350-356.

Gutell, R.R. (1994). Collection of small subunit (16S- and 16S-like) ribosomal RNA structures. Nucleic Acids Research, 22, 3502-3507

Haglund, K. (1997). The use of algae in aquatic toxicity assessment. In: Round, F.E., Chapman, D.J. (Eds.), Progress in Phycological Research. Biopress Ltd., Bristol (England), 181-212.

Hense, B. A.; Juttner, I.; Welzl, G.; Severin, G. F.; Pfister, G., Behechti, A. \& Schramm, K. W. (2003). Effects of 4-nonylphenol on phytoplankton and periphyton in aquatic microcosms. Environmental Toxicology and Chemistry, 22, 2727-2732.

Horth, H. \& Blackmore, K. (2009). Survey of glyphosate and AMPA in Europe, WRc Report UC 8073.02, WRc plc, Frankland Road, Blagrove, Swindon, Wiltshire, SN5 8YF, England (Confidential report to Monsanto Europe).

Huber, A.; Bach, M. \& Frede, H.G. (2000). Pollution of surface waters with pesticides in Germany: modeling non-point source inputs. Agriculture, Ecosystems and Environment, 80, 191-204.

Hughes, J. (1987a). The toxicity of glyphosate technical to Anabaena flos-aquae: Lab Project ID: 1092-02-1100-4. Unpublished study prepared by Malcolm Pirnie, 23, In: US EPA. (1993). Reregistration Eligibility Decision (RED) for Glyphosate. EPA 738-R-93-014 Office of Preventions, Pesticides and Toxic Substances. September 1993.

Hughes, J. (1987b). The toxicity of glyphosate technical to Navicula pelliculosa: Lab Project ID: 1092-02-1100-2. Unpublished study prepared by Malcolm Pirnie, 23, In: US EPA. (1993). Reregistration Eligibility Decision (RED) for Glyphosate. EPA 738-R-93-014 Office of Preventions, Pesticides and Toxic Substances. September 1993.

Hughes, J. (1987c). The toxicity of glyphosate technical to Selenastrum capricornutum: Lab Project ID: 1092-02-1100-1. Unpublished study prepared by Malcolm Pirnie, 23, In: US EPA. (1993). Reregistration Eligibility Decision (RED) for Glyphosate. EPA 738R-93-014 Office of Preventions, Pesticides and Toxic Substances. September 1993.

Hutber, G.N.; Rogers, L.J. \& Smith, A.J. (1979). Influence of pesticides on the growth of cyanobacteria. Zeitschrift für allgemeine Mikrobiologie, 19, 397-402.

IFEN (2006). Les pesticides dans les eaux- Données 2003 et 2004 (Pesticides in water, Data from 2003 and 2004), Institut Français de l'Environnement, Orléans, France (in French).

IFEN (2007). Les pesticides dans les eaux- Données 2005 (Pesticides in water, Data from 2005), Institut Français de l'Environnement, Orléans, France (in French). 
IFEN (2009). Les pesticides dans les eaux (Pesticides in waters), http://www.stats. environnement.developpement-durable.gouv.fr/donnees-essentielles/eau/lespesticides-dans-les-eaux.html (accessed in July 2010).

Jöhnk, K.D.; Huisman, J.; Sharples, J.; Sommeijer, B.; Visser, P. \& Strooms, M. (2008). Summer heatwaves promote blooms of harmful cyanobacteria. Global Change Biology, 14, 495-512.

Keddy C.; Greene J.C., \& Bonnell M.A. (1994). Examen des biotests effectués sur des organismes entiers pour l'évaluation de la qualité des sols, des sédiments et des eaux douces au Canada. Environnement Canada, Direction générale de la Conservation des écosystèmes, Ottawa, Ontario, Etude Nº198.

Kolpin, D.W.; Thurman, E.M.; Lee, E.A.; Meyer, M.T.; Furlong, E.T.; Glassmeyer, S.T., et al. (2006). Urban contributions of glyphosate and its degradate AMPA to streams in the United States. Environmental Science and Technology, 354, 191-197.

Konstantinou, I.K.; Hela, D.G. \& Albanis T.A. (2006). The status of pesticide pollution in surface waters (rivers and lakes) of Greece. Part I. Review on occurrence and levels. Environmental Pollution, 141, 555-570.

Kreuger, J. (1998). Pesticides in stream water within an agricultural catchment in southern Sweden. The Science of the Total Environment, 216, 227-251.

Langiano, V.C. \& Martinez, C.B.R. (2008). Toxicity and effects of a glyphosate-based herbicide on the neotropical fish Prochilodus lineatus. Comparative Biochemistry and Physiology Part C: Toxicology \& Pharmacology, 147, 222-231.

LISEC (1989a). Alga, growth inhibition test. Effect of MON 2139 on the growth of Selenastrum capricornutum. Unpublished report submitted by Monsanto, In: WHO (1994). Glyphosate - Environmental Health Criteria No 159. International Programme on Chemical Safety (IPCS), Geneva

LISEC (1989b). Alga, growth inhibition test. Effect of MON 8755 on the growth of Selenastrum capricornutum. In Unpublished report submitted by Monsanto, In: WHO (1994). Glyphosate - Environmental Health Criteria No 159. International Programme on Chemical Safety (IPCS), Geneva.

López-Rodas, V.; Flores-Moya, A.; Maneiro, E.; Perdigones, N.; Marva, F.; Marta, G.E., et al. (2007). Resistance to glyphosate in the cyanobacterium Microcystis aeruginosa as result of pre-selective mutations. Evolutionary Ecology, 21, 535-547.

Lee, T.H.; Kurata, S.; Nakatsu, C.H. \& Kamagata, Y. (2005). Molecular analysis of bacterial community based on $16 \mathrm{~S}$ rDNA and functional genes in activated sludge enriched with 2,4-dichlorophenoxyacetic acid (2,4-D) under different cultural conditions. Microbial Ecology, 49, 151-162.

López-Doval, J.C. ; Ricart, M. ; Guasch, H. ; Romani, A.M. ; Sabater, S. \& Muñoz, I. (2010). Does grazing pressure modify diuron toxicity in a biofilm community. Archives of Environmental Contamination and Toxicology, 58, 955-962.

Lürling, M. \& Roessink, I. (2006). On the way to cyanobacterial blooms: Impact of the herbicide metribuzin on the competition between a green alga (Scenedesmus) and a cyanobacterium (Microcystis). Chemosphere, 65, 618-626.

Lyautey, E.; Teissier, S.; Charcosset, J. Y.; Rols, J.L. \& Garabetian, F. (2003). Bacterial diversity of epilithic biofilm assemblages of an anthropised river section, assessed by DGGE analysis of a 16S rDNA fragment. Aquatic Microbial Ecology, 33, 217-224. 
Ma, J. (2002). Differential sensitivity to 30 herbicides among populations of two green algae Scenedesmus obliquus and Chlorella pyrenoidosa. Bulletin of Environmental Contamination and Toxicology, 68, 275-281.

Ma, J. \& Wang, S. (2002). A quick, simple, and accurate method of screening herbicide activity using green algae cell suspension cultures. Weed Science Society of America, 50, 555-559.

Ma, J.; Lin, F.; Wang, S. \& Xu, L. (2003). Toxicity of 21 herbicides to the green alga Scenedesmus quadricauda. Bulletin of Environmental Contamination and Toxicology 71, 594-601.

Ma, J.; Xu, L.; Wang, S.; Zheng, R.; Jin, S.; Huang, S. et al. (2002). Toxicity of 40 herbicides to the green alga Chlorella vulgaris. Ecotoxicology and Environmental Safety, 132, 128-132.

Mallat, E. \& Barceló, D. (1998). Analysis and degradation study of glyphosate and of aminomethylphosphonic acid in natural waters by means of polymeric and ionexchange solid-phase extraction columns followed by ion chromatography-post column derivatization with fluorescence detection. Journal of Chromatography A, 823, 129-136.

Maule, A. \& Wright, S.J. (1984). Herbicide effects on the population growth of some green algae and cyanobacteria. Journal of Applied Bacteriology, 57, 369-379.

Macur, R.E.; Wheeler, J.T.; Burr, M.D. \& Inskeep W.P. (2007). Impacts of 2,4-D application on soil microbial community structure and on populations associated with 2.,4-D degradation. Microbiological Research, 162, 37-45.

Monsanto (1990). Dissipation of glyphosate and aminomethylphosphonic acid in forestry sites (Unpublished report No. MSL-9940), In: WHO (1994). Glyphosate Environmental Health Criteria No 159. International Programme on Chemical Safety (IPCS), Geneva.

Muñoz, I.; Real, M.; Guasch, H.; Navarro, E. \& Sabater, S. (2001). Effects of atrazine on periphyton under grazing pressure. Aquatic Toxicology, 55, 239-249.

Muyzer, G. (1999). DGGE/TGGE a method to identifying genes from natural ecosystems. Current Opinion in Microbiology, 2, 317 - 322

Na, T.; Fang, Z.; Zhanqi, G.; Ming, Z. \& Cheng, S. (2006). The status of pesticide residues in the drinkingwater sources in Mailiangwan bay, Taihu lake of China. Environmental Monitoring and Assessment, 123, 351-370.

Nelson, K. ; Methé, B.A. \& Kowalchuk, G.A. (2006). Environmental Microbial Ecology in an «Omics» Era. Summary report of MicroEnGen-II (Shanghai, June 12-15, 2006). Microbial Ecology, 53, 369-370.

Neufeld, J.D. ; Wagner, M. \& Murrell, J.C. (2007). Who eats, what, where and when? Isotopelabelling experiments are coming of age. The ISME Journal, 1, 103-110.

Neumann, M. ; Liess, M. \& Schultz, R. (2003). A qualitative method for monitoring water quality in temporary channels or point sources and its application to pesticide contaminbation. Chemosphere, 51, 509-513.

Novack, B. (1997). Determination of phosphonates in natural waters by ion-pair high performance liquid chromatography. Journal of Chromatography A, 773, 139-146.

Office of Pesticide Programs. (2000). Pesticide Ecotoxicity Database. Environmental Fate and Effects Division, U.S.EPA, Washington, DC. 
Oldenburg, G.; Griner, E.M.; Francis, C.A. \& Ward, B.B. (2003). Oligonucleotide microarray for the study of functional gene diversity in the nitrogen cycle in the environment. Applied of Environmental Microbiology. 69, 1159-1171.

Park, J. ; Congeevaram, S. ; Ki, D.W \& Tiedje, J.M. (2006). Use of stable isotope probing in selective isolating target microbial community genomes from environmental samples for enhancing resolution in ecotoxicological assessment. Molecular $\mathcal{E}$ Cellular Toxicology, 2, 11-14.

Pereira, J. L.; Antunes, S.C.; Castro, B.B.; Marques, C.R.; Gonçalves, A.M.; Pereira, R. et al. (2009). Toxicity evaluation of three pesticides on non-target aquatic and soil organisms : commercial formulation versus active ingredient. Ecotoxicology, 18, 455463.

Pérès, F.; Florin, D.; Grollier, T.; Feurtet-Mazel, A.; Coste, M.; Ribeyre, F.; Ricard, M. \& Boudou, A. (1996). Effects of the phenylurea herbicide isoproturon on periphytic communities in freshwater indoor microcosms. Environmental Pollution. 94, 141-152.

Pérez, G.L. ; Torremorell, A. ; Mugni, H. ; Rodriguez, P. ; Vera, M.S. ; do Nascimento, M. ; Allende, L. ; Bustingorry, J. ; Escaray, R. ; Ferraro, M. ; Izaguirre, I. ; Pizarro, H. ; Bonetto, C. ; Morris, D.P. \& Zagarese, H. (2007). Effects of the herbicide Roundup on freshwater microbial communities: A mesocosm study. Ecological Applications, $17,2310-2322$.

Peruzzo, P.J.; Porta, A.A. \& Ronco, A.E. (2008). Levels of glyphosate in surface waters, sediments and soils associated with direct sowing soybean cultivation in north pampasic region of Argentina. Environmental Pollution, 156, 61-66.

Pesce, S.; Batisson, I.; Bardot, C.; Fajon, C.; Portelli, C.; Montuelle, B. \& Bohatier, J. (2009a). Response of spring and summer riverine microbial communities following glyphosate exposure. Ecotoxicology and Environmental Safety, 72, 1905-1912

Pesce, S.; Martin-Laurent F.; Rouard N.; \& Montuelle, B. (2009b). Potential for microbial diuron mineralization in a small wine-growing watershed: from treated plots to lotic receiver hydrosystem. Pesticide Management, 65, 651-657.

Pesce, S.; Fajon, C.; Bardot, C.; Bonnemoy, F.; Portelli, C. \& Bohatier, J. (2006). Effects of the phenylurea herbicide diuron on natural riverine microbial communities in an experimental study. Aquatic Toxicology, 78, 303-314.

Pesce, S.; Fajon, C.; Bardot, C.; Portelli, C. \& Bohatier, J. (2008). Longitudinal changes in microbial planktonic communities of a French river in relation to pesticide and nutrient inputs. Aquatic Toxicology, 86, 352-360.

Peterson, H.G.; Boutin, C.; Martin, P.A.; Freemark, K.E.; Ruecker, N.J.; Moody, M.J. et al. (1994). Aquatic phyto-toxicity of 23 pesticides applied at expected environmental concentrations. Aquatic Toxicology, 28, 275-292.

Pipke, R. \& Amrhein, N. (1988). Degradation of the phosphonate herbicide glyphosate by Arthrobacter atrocyaneus ATCC 13752. Applied and Environmental Microbiology, 54, 1293-1296.

Powell, H.A. ; Kerbby, N.W. \& Rowell, P. (1991). Natural tolerance of cyanobacteria to the herbicide glyphosate. New Phytologist, 119, 421-426.

Prado, R.; Rioboo, C.; Herrero, C. \& Cid, A. (2009). The herbicide paraquat induces alterations in the elemental and biochemical composition of non-target microalgal species. Chemosphere, 76, 1440-1444

Ramade, F. (2007). Introduction à l'écotoxicologie. Ed : Dunod, Paris. 550pp. 
Rand, G. M.; Clark, J. R. \& Holmes, C. M. (2000). Use of outdoor freshwater pond microcosms: I. Microcosm design and fate of pyridaben. Environmental Toxicology and Chemistry, 19, 387-395.

Ricart, M.; Barcelo, D.; Geiszinger, A.; Guasch, H.; Lopez de Alda, M.; Romani, A.M.; Vidal, G., Villagrasa, M. \& Sabater S. (2009). Effects of low concentration of the phenylurea herbicide diuron on biofilm algae and bacteria. Chemosphere, 76: 13921401.

Ricciardi, F.; Bonnineau, C.; Faggiano, L.; Geizinger, A.; Guasch, H.; Lopez-Doval, J.; Muñoz, I.; Ricart, M.; Romani, A. \& Sabater, S. (2009). Is chemical contamination linked to the diversity of biological communities in rivers? Trends in Analytical Chemistry, 28, 592-602.

Riemann, L. \& Winding, A. (2001). Community dynamics of free-living and particleassociated bacterial assemblages during a freshwater phytoplankton bloom. Microbial Ecology, 42, 274-285.

Rioboo, C.; González, O.; Herrero, C. \& Cid, A. (2002). Physiological response of freshwater microalga (Chlorella vulgaris) to triazine and phenylurea herbicides. Aquatic Toxicology, 59, 225-235.

Rueppel, M.L.; Brightwell, B.B.; Schaefer, J. \& Marvel, J.T. (1977). Metabolism and degradation of glyphosate in soil and water. Journal of Agricultural and Food and Chemistry, 25(3), 517-528.

Sabater, S.; Guasch, H.; Ricart, M.; Romani, A.; Vidal, G.; Klunder, C. \& Schmitt-Jansen, M. (2007). Monitoring the effect of chemicals on biological communities. The biofilm as an interface. Analytical and Bioanalytical Chemistry, 387, 1425-1434.

Sáenz, M.E. \& Di Marzio, W.D. (2009). Ecotoxicidad del herbicida Glifosato sobre cuatro algas clorófitas dulceacuícolas, Limnetica, 28, 149-158.

Sáenz, M.E. ; Di Marzio, W.D. ; Alberdi, J.L. \& del Carmen Tortorelli, M. (1997). Effects of technical grade and a commercial formulation of glycphosate on algal population growth. Bulletin of Environmental Contamination and Toxicology, 59, 638-644.

Schauer, M.; Balague, V.; Pedros-Alio, C. \&. Massana, R. (2003). Seasonal changes in the taxonomic composition of bacterioplankton in a coastal oligotrophic system. Aquatic Microbial Ecology, 31, 163-174.

Schmitt-Jansen, M. \& Altenburger, R. (2005). Predicting and observing responses of algal communities to photosystem II - Herbicide exposure using pollution-induced community tolerance and species-sensitivity distributions. Environmental Toxicology and Chemistry, 24, 304-312.

Schuler, L.J. \& Rand, G.M. (2008). Aquatic risk assessment of herbicides in freshwater ecosystems of south Florida. Archives of Environmental Contamination and Toxicology, 54, 571-583.

Scribner, E.A.; Battaglin, W.A.; Gilliom, R.J. \& Meyer, M.T. (2007). Concentrations of glyphosate, its degradation product, aminomethylphosphonic acid, and glufosinate in ground- and surface-water, rainfall, and soil samples collected in the United States, 2001-06- Scientific Investigations Report 2007-5122, U.S. Geological Survey, Reston, Virginia.

Shabana, Y.M.; Elwakil, M.A. \& Charudattan, R. (2001). Effect of nutrittion and physical factors on mycelial growth and production of pigments and non-chromatic UVabsorbing compounds of Alternaria eichhorniae. Journal of Phytopathology, 149, 21-27 
Shipitalo, M.J. \& Owens, L.B. (2006). Tillage system, application rate, and extreme event effects on herbicide losses in surface runoff. Journal of Environmental Quality, 35, 2186-2194.

Skark, C.; Zullei-Seibert, N.; Schottler, U. \& Schlett, C. (1998). The occurrence of glyphosate in surface water. International Journal of Environmental Analytical Chemistry, 70, 93104.

Smyth, D.; Kent, S.; Morris, D. et al. (1996). Glyphosate acid: toxicity to the freshwater diatom (Navicula pelliculosa): Lab Project Number: BL5673/B: AB0503/K. Unpublished study prepared by Zeneca Limited, 25, In: Durkin, P.R. (2003) Glyphosate, Human health and ecological risk assessment. USDA forest service, Arlington.

Smyth, D.; Kent, S.; Morris, D. et al. (1995). Glyphosate acid: acute toxicity to the green alga (Selenastrum capricornutum): Lab Project Number: BL5550/B: AB0503/B. Unpublished study prepared by Zeneca Limited, 24, In: Durkin, P.R. (2003) Glyphosate, Human health and ecological risk assessment. USDA forest service, Arlington.

Smyth, D.; Shillabeer, N.; Morris, D. et al (1996). Glyphosate acid: acute toxicity to the bluegreen Alga (Anabaena flos-aquae): Lab Project Number: BL5698/B: AB0503/J. Unpublished study prepared by Zeneca Limited., 25, In: Durkin, P.R. (2003) Glyphosate, Human health and ecological risk assessment. USDA forest service, Arlington.

Spalding, R.F. \& Snow, D.D. (1989). Stream levels of agrichemicals during a spring discharge event. Chemosphere, 19, 1129-1140.

Sprankle, P.; Meggitt, W.F.; Penner, D.; Science, S.W. \& May, N. (1975). Adsorption, mobility, and microbial degradation of glyphosate in the soil. Weed Science Society of America, 23, 229-234.

Struger, J.; Thompson, D.; Bozena, S.; Martin, P.; Mcdaniel, T.; Marvin, C. et al. (2008). Occurrence of glyphosate in surface waters of southern Ontario. Bulletin of Environmental Contamination and Toxicology, 80, 378-384.

Sudo, M. ; Kawachi, T. ; Hida, Y. \& Kunimatsu T. (2004). Spatial distribution and seasonal changes of pesticides in lake Biwa, Japan. Limnology, 5, 77-86.

Sudo, M.; Kunimatsu, T. \& Okubo, T. (2002). Concentration and loading of pesticides resisdues in lake Biwa basin (Japan). Water Research, 36, 315-329.

Tadonléké, R.; Le Berre, B.; Perreau, F. \& Humbert, J.F. (2009). Responses of lake bacterioplankton activities and composition to the herbicide diuron. Aquatic Toxicology, 94, 103-113.

Tomlin, C.D. (1997). The pesticide manual 11th, British Crop Protection Council, Farnham Surrey, UK.

Tooby, T.E. (1985). Fate and biological consequences of glyphosate in the aquatic environment, In: The herbicide glyphosate, Grossbard, E. \& Atkinson, D. (Ed.), Butterworth and Co. London.

Trass, T.P. \& Smit, C.E. (2003). Environmental risk limits for aminomethylphosphonic acid (AMPA) RIVM report 601501018/2003. National Institute of Public Health and the Environment. Bilthoven, The Netherlands. 
Tsui, M.T. \& Chu, L.M. (2003). Aquatic toxicity of glyphosate-based formulations: comparison between different organisms and the effects of environmental factors. Chemosphere, 52, 1189-1197.

Vandenkoornhuyse, P.; Dufresne, A.; Quaiser, A.; Gouesbet, G.; Binet, F.; Francez, A.J.; Mahé, S.; Bormans, M.; Lagadeuc, Y. \& Coué, I. (2010). Integration of molecular functions at the ecosystemic level: breakthroughs and future goals of environmental genomics and post-genomics. Ecology Letters, 13, 776-791.

Vendrell, E.; Ferraz, D.G.; Sabater, C. \& Carrasco, J.M. (2009). Effect of glyphosate on growth of four freshwater species of phytoplankton : A microplate bioassay. Bulletin of Environmental Contamination and Toxicology, 82, 538-542.

Vera, M.S.; Lagomarsino, L.; Sylvester, M.; Pérez, G.L.; Rodriguez, P.; Mugni, H.; Sinistro, R.; Ferraro, M.; Bonetto, C.; Zagares, H. \& Pizarro, H. (2010). New evidence of Roundup (glyphosate formulation) impact on periphyton community and the water quality of freshwater ecosystems. Ecotoxicology, 19, 710-721

Villeneuve, A. (2008). Effets conjoints de facteurs physiques et chimiques sur la structure et la composition du periphyton : une approche multi-échelle. These de L'université de Savoie.

Ware, G. W., \& Whitacre, D. M. (2004). The Pesticide Book (6th ed). Willoughby, Ohio: Meister Media Worldwide, $496 \mathrm{pp}$.

Wauchope, R.D. (1978). The pesticide content of surface water draining from agricultural fields: A review. Journal of Environmental Quality, 7, 459-472.

WHO (1994). Glyphosate - Environmental Health Criteria No 159. International Programme on Chemical Safety (IPCS), Geneva.

Widenfalk, A.; Bertilsson, S.; Sundh, I. \& Goedkoop, W. (2008). Effects of pesticides on community composition and activity of sediment microbes - Responses at various levels of microbial community organization. Environmental Pollution, 152, 576-584.

Wilson, M.A. \& Carpenter S.R. (1999). Economic valuation of freshwater ecosystem services in the United States: 1971-1997. Ecological Applications, 9, 772-783.

Wittmer, I.K.; Bader, H.-P.; Scheidegger, R.; Singer, H.; Lück, A.; Hanke, I.; Carlsson, C. \& Stamm, C. (2010). Significance of urban and agricultural land use of biocide and pesticide dynamics in surface waters. Water Research, 44, 2850-2862.

Wong, P.K. (2000). Effects of 2, 4-D, glyphosate and paraquat on growth, photosynthesis and chlorophyll-a synthesis of Scenedesmus quadricauda Berb 614. Chemosphere, 41, 177182.

Woodburn, A.T. (2000). Glyphosate : production, pricing and use. Pest Management Science, 56, 309-312.

Yoshida, K.; Igarashi, E.; Mukai, M.; Hirata, K. \& Miyamoto, K. (2003). Induction of tolerance to oxidative stress in the green alga, Chlamydomonas reinhardtii, by abscisic acid. Plant Cell Environment, 26, 451-457. 


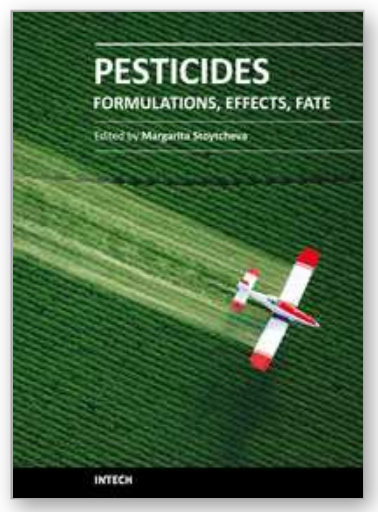

\author{
Pesticides - Formulations, Effects, Fate \\ Edited by Prof. Margarita Stoytcheva
}

ISBN 978-953-307-532-7

Hard cover, 808 pages

Publisher InTech

Published online 21, January, 2011

Published in print edition January, 2011

This book provides an overview on a large variety of pesticide-related topics, organized in three sections. The first part is dedicated to the "safer" pesticides derived from natural materials, the design and the optimization of pesticides formulations, and the techniques for pesticides application. The second part is intended to demonstrate the agricultural products, environmental and biota pesticides contamination and the impacts of the pesticides presence on the ecosystems. The third part presents current investigations of the naturally occurring pesticides degradation phenomena, the environmental effects of the break down products, and different approaches to pesticides residues treatment. Written by leading experts in their respective areas, the book is highly recommended to the professionals, interested in pesticides issues.

\title{
How to reference
}

In order to correctly reference this scholarly work, feel free to copy and paste the following:

Villeneuve A., Larroudé S. and Humbert J.F. (2011). Herbicide Contamination of Freshwater Ecosystems: Impact on Microbial Communities, Pesticides - Formulations, Effects, Fate, Prof. Margarita Stoytcheva (Ed.), ISBN: 978-953-307-532-7, InTech, Available from: http://www.intechopen.com/books/pesticides-formulationseffects-fate/herbicide-contamination-of-freshwater-ecosystems-impact-on-microbial-communities

\section{INTECH}

open science | open minds

\section{InTech Europe}

University Campus STeP Ri

Slavka Krautzeka 83/A

51000 Rijeka, Croatia

Phone: +385 (51) 770447

Fax: +385 (51) 686166

www.intechopen.com

\section{InTech China}

Unit 405, Office Block, Hotel Equatorial Shanghai

No.65, Yan An Road (West), Shanghai, 200040, China

中国上海市延安西路65号上海国际贵都大饭店办公楼405单元

Phone: +86-21-62489820

Fax: +86-21-62489821 
(C) 2011 The Author(s). Licensee IntechOpen. This chapter is distributed under the terms of the Creative Commons Attribution-NonCommercialShareAlike-3.0 License, which permits use, distribution and reproduction for non-commercial purposes, provided the original is properly cited and derivative works building on this content are distributed under the same license. 